\title{
Evaluation of the catalytic activity of lipases immobilized on chrysotile for esterification
}

\author{
JANE E.S. SILVA and PAULO C. JESUS \\ Universidade Regional de Blumenau, Departamento de Química, Campus I \\ 89010-971 Blumenau, SC, Brasil \\ Manuscript received on February 19, 2001; accepted for publication on December 12, 2002; \\ presented by Fernando GaLEMBECK
}

\begin{abstract}
In the present work, the ester synthesis in organic media catalyzed by lipases immobilized on chrysotile was studied. Lipases of different sources (Mucor javanicus, Pseudomonas cepacia, Rhizopus oryzae, Aspergillus niger and Candida rugosa) were immobilized on chrysotile, an inexpensive magnesium silicate, and used for esterification of hexanoic, octanoic and lauric acid with methanol, ethanol, 1-butanol and 1-octanol at $25^{\circ} \mathrm{C}$ in hexane as solvent. The best results were obtained with Mucor javanicus lipase and lauric acid giving yields of $62-97 \%$ of ester.
\end{abstract}

Key words: chrysotile, lipases, esters.

\section{INTRODUCTION}

Lipases (triacyglicerol acylhydrolase, EC 3.1.1.3) are enzymes that catalyse hydrolysis of acylglicerides and other fatty acid esters. They are present in several organisms, including animals, plants, fungi and bacteria. They have been attracting the attention of chemical organic synthesis mainly because of their enantioselective properties. Lipases have been widely used in organic synthesis due to their catalytic versatility, commercial availability, low cost and non request cofactors (Jesus et al. 1995, Faber 1997). On the other hand, biocatalysis in nonaqueous media has emerged as a powerful tool for the production of fine chemicals, pharmaceuticals and food ingredients. Advantages commonly associated with the use of organic solvents as reaction media include improved solubility and chemical sta-

Correspondence to: Paulo C. Jesus

E-mail: pcj@furb.rct-sc.br bility of the organic substrates and facile product recovery (Green et al. 1996).

The immobilization of enzymes in a solid matrix has been widely investigated and a variety of supporting media has been tested (Lima et al. 1996, Oliveira et al. 2000). Efforts have been directed towards the finding of good supports for the immobilization of lipases. Immobilization methods have been developed to supply stability for the lipases in organic media and to facilitate their recovery and reuse. Among the different types of supports that were studied in literature chrysotile appeared to be a further alternative. Chrysotile, one of the main asbestos sources used extensively in the civil construction, has shown excellent adsorption properties due to the high specific area. It is a magnesium silicate of the serpentine group, presenting the molecular formula $\mathrm{Mg}_{3}\left(\mathrm{Si}_{2} \mathrm{O}_{5}\right)(\mathrm{OH})_{4}$, with $43 \%$ of $\mathrm{MgO}$, $44,1 \%$ of $\mathrm{SiO}_{2}, 12,9 \%$ of $\mathrm{H}_{2} \mathrm{O}$ (Jesus et al. 1998).

Moran et al. studied the immobilization of 
Baker's yeast on chrysotile and its application for the stereoselective reduction of carbonyl compounds such as $\alpha$-azidopropiophenone. They obtained the azidoalcohols, the corresponding optically active products, with good yields and enantiomeric excess (Moran et al. 1994). Other works used Baker's yeast immobilized on chrysotile for the reduction of phenylketones (Sorrilha et al. 1992), $\alpha$ haloacetophenones (Carvalho et al. 1991, Aleixo et al. 1993), and the enantioselective synthesis of (R)(-)-1-phenylethanolamines (Brenelli et al. 1992). Lipase from Candida cylindracea was also immobilized on chrysotile and used successfully in organic synthesis (Lima et al. 1996).

In the present work we used chrysotile as a support for the immobilization of different lipases (lipase from Mucor javanicus, Pseudomonas cepacia, Rhizopus oryzae, Candida rugosa and Aspergillus niger) in the production of esters. They are very important flavour compounds and are widespread in nature in a great variety of foodstuffs.

\section{EXPERIMENTAL}

\subsection{Materials And Methods}

The lipases used in this work were from Pseudomonas cepacia (Amano PS) with specific activity of 30,000 U/g solid, from Candida rugosa (AY Amano 30) with 30,000 U/g solid, from Aspergillus niger (Amano 12) with 12,000 U/g solid, from $\mathrm{Mu}$ cor javanicus (Amano 10) with 10,000 U/g solid and from Rhizopus oryzae (F-AP 15) with 150,000 U/g solid. Enzymes were kindly supplied by Amano Enzymes Pharmaceutical Co. The alcohols methanol, ethanol, 1-butanol, 1-pentanol, 1-octanol and hexanoic, octanoic and lauric acid were from Vetec (Brazil). All solvents and reagents were analytical grade. The chrysotile type 5RL was supplied by the SAMA'S mine (Goiás - Brazil). The ${ }^{1} \mathrm{H}$ NMR spectra were recorded in $\mathrm{CDCl}_{3}$-solutions with TMS as reference on a Bruker AC 200 spectrometer. Infrared spectra were obtained by using a Perkin-Elmer model 16PC FTIR spectrophotometer. The amount of lipase adsorbed by chrysotile was estimated by UV spectra, on a Metrolab 1700 spectrometer.

\subsection{Immobilization Process}

The preparation of chrysotile for immobilization of the enzymes has been described previously (Jesus et al. 1998). The lipases from Pseudomonas cepacia, Candida rugosa, Aspergillus niger, Mucor javanicus and Rhizopus oryzae were immobilized on chrysotile as follows: $0.2 \mathrm{~g}$ of enzyme in $100 \mathrm{~mL}$ of sodium phosphate buffer ( $\mathrm{pH}$ 7.2) was added to $1.0 \mathrm{~g}$ of chrysotile and the resulting suspension was shaken for $24 \mathrm{~h}$ at $25^{\circ} \mathrm{C}$. The suspension was filtered under vacuum and the solid was air dried.

\subsection{ESTERIFICATION REACTION}

$1 \mathrm{~g}$ of chrysotile with immobilized enzyme $(140 \mathrm{mg}$ of lipase) was transferred to an erlenmeyer with $25 \mathrm{~mL}$ of hexane. Equimolar amounts $(0,01 \mathrm{~mol}$ each) of the reactants (acids: hexanoic, octanoic and lauric; alcohols: methanol, ethanol, 1-butanol, 1-pentanol and 1-octanol) were added to the erlenmeyer. The mixtures were shaken in an incubator at $25^{\circ} \mathrm{C}$ for 48 hours. The reactions were monitored by ${ }^{1} \mathrm{H}$ NMR and Thin-Layer Chromatography (TLC) analysis of samples taken periodically from the reaction mixtures. Isolation of the esters was performed by column chromatography with silica gel 60 (70-230 mesh) and hexane:ethylacetate 15:1 as eluent (Figure 1).

Control reactions were done under the same experimental conditions using chrysotile without adsorbed enzyme.

\section{RESULTS AND DISCUSSION}

Five different lipases (Rhizopus oryzae, Aspergillus niger, Candida rugosa, Mucor javanicus and Pseudomonas cepacia lipases) were immobilized on chrysotile and used in the esterification of hexanoic, octanoic and lauric acid with methanol, ethanol, 1butanol, 1-pentanol and 1-octanol as shown in Figure 1 . The amount of lipase adsorbed by chrysotile was $70 \%$, with the exception of Aspergillus niger 


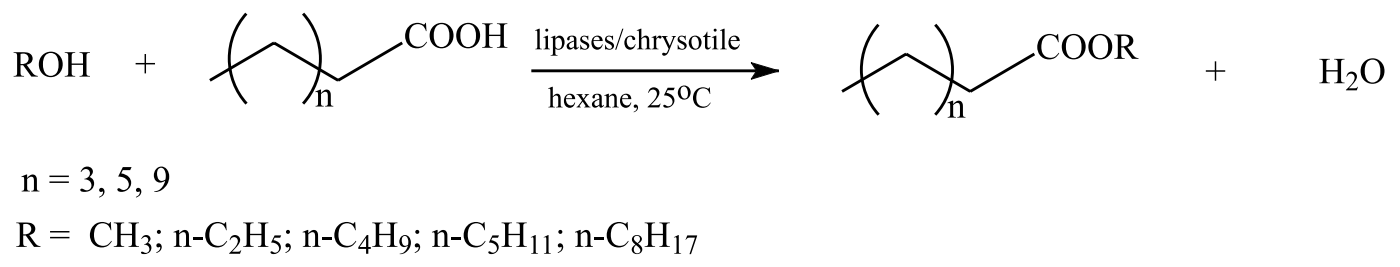

Fig. 1 - Esterification reaction catalyzed by lipases immobilized on chrysotile.

lipase with $30 \%$ immobilized. The results obtained for the esterifications with the different lipases immobilized on chrysotile are shown in Table I and II.

\section{TABLE I}

Esters obtained by the esterification catalyzed by Mucor javanicus lipases immobilized on chrysotile at $25^{\circ} \mathbf{C}^{(a)}$

\begin{tabular}{c|c|c}
\hline Acids & Ester & Yields $(\%)^{\mathrm{b}}$ \\
\hline hexanoic & methyl hexanoate & 49 \\
& ethyl hexanoate & 41 \\
& n-butyl hexanoate & 64 \\
& n-pentyl hexanoate & 66 \\
\hline \multirow{2}{*}{ octanoic } & methyl octanoate & 64 \\
& ethyl octanoate & 69 \\
& n-butyl octanoate & 76 \\
& n-pentyl octanoate & 77 \\
& n-octyl octanoate & 78 \\
\hline lauric & methyl laurate & 62 \\
& ethyl laurate & 65 \\
& n-butyl laurate & 97 \\
& n-pentyl laurate & 82 \\
& n-octyl laurate & 84 \\
\hline
\end{tabular}

(a) reaction conditions: time 48 hours, 0,01 mol substrate (1:1), solvent hexane (under agitation); (b) Yields of esters isolated by chromatography using as eluent hexane:ethylacetate (15:1).

It can be observed that the best results were achieved with lauric acid, with yields from $62 \%$ to 97\%. Carboxylic acids with more then 8 carbons have been shown to be a better substrate for lipases (Jesus et al. 1997). From Table II it can be seen that, except Aspergillus niger lipase, all lipases exhibited good catalytic activity in the esterification reaction, differing in the yields of esters. The poor catalytic performance of Aspergillus niger lipase is probably due to its low amount adsorbed on chrysotile (60 $\mathrm{mg}$ ) and its low catalytic activity. The adsorption process can influence the conformation of the lipase and therefore its catalytic activity.

The Mucor javanicus lipase showed to be more efficient than the other lipases when immobilized on chrysotile. Concerning the different acids employed, it can be seen from Table I that the most lipophilic lauric acid reacted with higher yields than the other acids. With lipases from Pseudomonas cepacia and Mucor javanicus n-butyl laurate was obtained with yields superior to $80 \%$.

The esters formed by the lauric acid are, in most cases liposoluble, due to their long carbon chains. Short and long chain esters produced by enzymatic synthesis may be applied as flavors, solvents, lubricants or plasticisers (Rocha et al. 1999). Concerning the different alcohol substrates, it can be seen from Table I that the best yield was achieved with 1-butanol. The reaction was done using chrysotile without adsorbed enzyme and no reaction was observed.

An important parameter of an immobilized enzyme preparation, in general, is the preservation of its catalytic activity throughout the immobilization procedure and the retention of this activity over prolonged periods of time. This study was accomplished for the esterification reaction of lauric acid and 1-pentanol catalyzed by Mucor javanicus lipase and the results can be observed in Table III, where 
TABLE II

Esters obtained by the esterification catalyzed by differents lipases immobilized on chrysotile at $25^{\circ} \mathrm{C}^{(a)}$

\begin{tabular}{c|c|c|c}
\hline Lipase & Acids & Ester & Yields $(\%)^{\mathrm{b}}$ \\
\hline Rhizopus oryzae & hexanoic & n-butyl hexanoate & 76 \\
& octanoic & n-butyl octanoate & 98 \\
& lauric & n-butyl laurate & 56 \\
\hline Aspergillus niger & hexanoic & n-butyl hexanoate & n.d $\mathrm{d}^{\mathrm{c}}$ \\
& octanoic & n-butyl octanoate & n.d $^{\mathrm{c}}$ \\
& lauric & n-butyl laurate & n.d \\
\hline \multirow{2}{*}{ Candida rugosa } & hexanoic & n-butyl hexanoate & 53 \\
& octanoic & n-butyl octanoate & 70 \\
& lauric & n-butyl laurate & 68 \\
\hline Pseudomonas cepacia & hexanoic & n-butyl hexanoate & 71 \\
& octanoic & n-butyl octanoate & 57 \\
& lauric & n-butyl laurate & 85 \\
\hline
\end{tabular}

(a) reaction conditions: time 48 hours, $0,01 \mathrm{~mol}$ substrate (1:1), solvent hexane (under agitation); (b) Yields of esters isolated by chromatography using as eluent hexane:ethylacetate (15:1); (c) n.d. $=$ not determined because of the low amount of ester obtained. Formation was evaluated by TLC chromatography.

\section{TABLE III}

Reuse of lipase from Mucor javanicus immobilized on chrysotile in the esterification reaction of 1-pentanol with lauric acid at $25^{\circ} \mathrm{C}^{(a)}$

\begin{tabular}{c|c|c|c}
\hline Alcohol & Ester & Used & Yields $(\%)^{\mathrm{b}}$ \\
\hline 1-pentanol & n-pentyl laurate & 1 & 82 \\
\cline { 3 - 4 } & & 2 & 80 \\
\cline { 3 - 4 } & & 3 & 25 \\
\cline { 3 - 4 } & & 4 & 24 \\
\hline
\end{tabular}

(a) reaction conditions: time 48 hours, 0,01 mol substrate (1:1), solvent hexane (under agitation); (b) Yields of esters isolated by chromatography using as eluent hexane:ethylacetate (15:1).

it can be seen that after the first reuse the yields of esters lowered by $25 \%$. As for the little reuse of the support, it probably does not result from leaching, as no desorption was observed. Probably, a modification in the enzyme structure related to the reuse pro- cess must be affecting the lipase conformation necessary to the catalysis, therefore, inactivating part of the enzyme molecule.

To compare the effect of the immobilization of the lipases the reaction of esterification of the 
lauric acid and 1-butanol was repeated in the same experimental conditions, 48 hours at $25^{\circ} \mathrm{C}$, using free lipases in hexane. No product formation was observed. Ahmad et al. (1998) have demonstrated that organic solvents may affect the reaction by direct by interacting with the enzyme. Enzymes need a small amount of water to retain their active threedimensional conformational state.

The catalytic performance of Mucor javanicus lipase to produce n-pentyl laurate in different organic solvents was observed, using the $\log \mathrm{P}$ as the polarity measurement (in which $\mathrm{P}$ is the partition coefficient between 1-octanol and water). In most cases, the enzymatic activity is low in relatively hydrophilic solvents, with $\log \mathrm{P}<2$; moderate in solvents with $\log \mathrm{P}$ between 2 and 4; and high in apolar solvents, where $\log \mathrm{P}>4$ (Chen and Sih 1989). The n-pentyl laurate yield was $82 \%$ in hexane (log $\mathrm{P}=3,5), 70 \%$ in cyclohexane $(\log \mathrm{P}=3,2), 68 \%$ in toluene $(\log \mathrm{P}=2,5)$ and no ester formation in dichloromethane $(\log \mathrm{P}=0,93)$, acetone ( $\log \mathrm{P}=$ $-0,23)$ and acetonitrile $(\log \mathrm{P}=-0,33)$ was observed.

\section{CONCLUSION}

Lipases of different sources were immobilized on chrysotile and applied successfully in the production of esters in organic media. With the exception of Aspergillus niger lipase, enzymes kept their catalytic activity. The use of immobilized enzymes on chrysotile may present many advantages such as simple performance and design of the bioreactor, facile recovery of the products, ready reuse of the biocatalyst and operational stability of the enzyme. Lipases act at the interface between hydrophobic and hydrophilic regions and, therefore, the immobilization in good support helps the biocatalysis.

The use of chrysotile with adsorbed lipases is, thus, a very attractive and viable alternative for enzymatic reactions in organic media.

\section{ACKNOWLEDGMENTS}

We are grateful to PIBIC/CNPq program for financing this work, Amano for supplying the enzymes and
DQ-UFSC for the ${ }^{1} \mathrm{H}$ NMR and IR analysis.

Editor's note: Chrysotile is now banned for any industrial applications in many parts of Brazil, due to concerns with its alleged toxicity.

\section{RESUMO}

Neste trabalho foi estudada a síntese de ésteres catalisada por lipases imobilizadas em crisotila (asbesto), em meio orgânico. Lipases de diferentes fontes (Mucor javanicus, Pseudomonas cepacia, Rhizopus oryzae, Aspergillus niger e Candida rugosa) foram imobilizadas em crisotila, um silicato magnesiano de baixo custo, e utilizadas na esterificação dos ácidos hexanóico, octanóico e láurico com metanol, etanol, 1-butanol, 1-pentanol e 1-octanol em hexano como solvente, a $25^{\circ} \mathrm{C}$. Os melhores resultados foram obtidos com a lipase de Mucor javanicus e o ácido láurico, obtendo-se ésteres com rendimentos entre 62 e $97 \%$.

Palavras-chave: asbesto, crisotila, lipases, ésteres.

\section{REFERENCES}

Ahmad RMY, William AA and Murray MY. 1998. Ester synthesis in lipase-catalyzed reactions. Enzyme Microb Technol 23: 438-450.

Aleixo LM, Carvalho M, Moran PJS and Rodrigues JAR. 1993. Hydride transfer versus electron transfer in baker's yeast reduction of $\alpha$-haloacetophenones. Bioorg Med Chem Lett 3: 1637-1642.

Brenelli ecs, Carvalho M, Okubo MT, MarQUeS M, MORAN PJS, RODRIGUeS JAR AND SorRILHA AEPM. 1992. Enantioselective synthesis of (R)-(-)-1-phenylethanolamines using baker's yeast reduction of some ( $\alpha$-substituted methyl phenyl ketones. Indian J Chem 31: 821-823.

Carvalho M, Okamoto MT, Moran PJS and RoDRIGUES JAR. 1991. Baker's yeast reduction of $\alpha$ haloacetophenones. Tetrahedron 47: 2073-2080.

Chen CS AND SiH CJ. 1989. General aspects and optimization of enantioselective biocatalysis in organic solvents: the use of lipases. Angew Chem Int Edn Engl 28: 695-707.

FABER K. 1997. Biotransformations in organic chemistry, $3^{\text {rd }}$ Edition, Spring-Verlag, New York, 1997, cap. 1 and 2 . 
Green KD, Gill IS, Khan JA and Vulfson EM. 1996. Microencapsulation of yeast cells and their use as a biocatalyst in organic solvents. Biotechnol Bioeng 49: $535-543$.

Jesus PC, Rezende MC and Nascimento MG. 1995. Enzymatic resolution of alcohols via lipases immobilized in microemulsion based-gels. Tetrahedron: Asymmetry 6: 63-66.

Jesus PC, João JJ, Silva PLF, Burlin G and NasciMENTO MG. 1997. Organo-gel: um novo sistema para a imobilização de lipases e sua aplicação em síntese orgânica. Quim Nova 20: 664-672.

Jesus PC, Silva PLF, João JJ and Nascimento MG. 1998. Enantioselective esterification of 2-methylpentanoic acid catalysed via immobilized lipases in chrysotile and microemulsion-based gels. Synth Commun 28: 2893-2901.

Lima C, Silva PlF, Nascimento MG and Rezende MC. 1996. The use of immobilized lipases on chrysotile for esterification reactions. J Braz Chem Soc 7: 173-175.
Moran PJS, Rodrigues JAR, Joekes I, BRenelli ECS AND Leite RA. 1994. Reduction of $\alpha$ azidopropiophenone by immobilized baker's yeast. Biocatalysis 9: 321-328.

Oliveira PC, Alves GM and Castro HF. 2000. Immobilisation studies and catalytic propertier of microbial lipase onto styrene-divinylbenzene copolymer. Biochem Eng J 5: 63-71.

Rocha JMS, Gil MH and Garcia FAP. 1999. Optimization of the enzymatic synthesis of n-octyl oleate with immobilised lipase in the absence of solvents. $\mathrm{J}$ Chem Technol Biotechnol 74: 607-612.

Sorrilha AEPM, Marques M, Joekes I, Moran PJS AND RODRIGUES JAR. 1992. Reduction of phenylketones by immobilized baker's yeast. Bioorg Med Chem Lett 2: 191-196. 